\title{
Appraisal of progenitor markers in the context of molecular classification of breast cancers
}

\author{
Izhak Haviv*1-3 \\ See related research by Keller et al., http://breast-cancer-research.com/content/12/5/R87
}

\begin{abstract}
Clinical management of breast cancer relies on case stratification, which increasingly employs molecular markers. The motivation behind delineating breast epithelial differentiation is to better target cancer cases through innate sensitivities bequeathed to the cancer from its normal progenitor state. A combination of histopathological and molecular classification of breast cancer cases suggests a role for progenitors in particular breast cancer cases. Although a remarkable fraction of the real tissue repertoire is maintained within a population of independent cell line cultures, some steps that are closer to the terminal differentiation state and that form a majority of primary human breast tissues are missing in the cell line cultures. This raises concerns about current breast cancer models.
\end{abstract}

The Heisenberg uncertainty principle has a great impact on medical research by drawing our attention to the bias introduced by our experimental tools. In a recent issue of Breast Cancer Research, Keller and colleagues [1] report an example of this principle: sustained propagation of large numbers of cells, through the establishment of cell lines, disrupts the normal balance between differentiated cells and their progenitors, as observed in fresh biological specimens. The work of these authors contributes another piece in a contentious field that combines tissue morphology and immunohistochemical phenotypes $[2,3]$, molecular classification of breast cancer tissues [4], and cell biological assays aimed at the tumor-initiating cell (TIC) phenotype [5]. Sorting cells according to their respective cell surface markers, $\mathrm{CD} 44^{+} / \mathrm{CD} 24^{-/ \text {low }}$, results

\footnotetext{
*Correspondence: izhak.haviv@petermac.org

'Systems Integration and Bioinformatics, The Blood and DNA Profiling Facility,

Baker IDI, 75 Commercial Road, Prahran, Vic, 3004 Australia

Full list of author information is available at the end of the article
}

in the enrichment of TIC activities, including mammospheres [6] and transplantation efficiency in mouse xenografts [7]. Establishing xenograft growth could be the product of several system-specific selections other than breast progenitor phenotypes. However, further molecular profiling of these cell populations - in which CD44 $/$ CD24-llow-sorted cells expressed low levels of luminal differentiation markers (such as MUC1, CD24, or CDH1) and elevated levels of epithelial-mesenchymal transition markers (such as VIM, collagens, TWIST1, SNAI1/2, and Zeb1/2) - indicated a link between epithelial-mesenchymal transition, TIC, and basal-like $[6,8]$ or claudin-low $[9,10]$-specific breast cancer molecular subtypes. More recently, however, a more comprehensive interrogation of pluripotent self-renewal identified a population high for CD24, or luminal progenitors [9,11-13], capable of giving rise to mesenchymal or basallike tumors, at least in the context of BrCa1 mutations. Given the variability of single markers within single individuals, the different sensitivities each cell biological assay presents with, and the consistency across other genes (which are more likely to be drivers of the phenotypes rather than effective surrogate markers), the more recent work presents compelling evidence that, admittedly, neither CD24 nor CD44 populations are homogenous or contain pure differentiated of progenitor populations, respectively. A hypothetical linear sequential differentiation track that would flip back and forth with respect to CD24 expression and appear as a hidden subpopulation in a majority of cells from another differentiation stage could explain this discrepancy. A more comprehensive whole-genome mRNA profiling analysis of the relatedness between luminal progenitors (CD49 $\mathrm{f}^{\text {hi }} /$ $\left.\mathrm{EpCAM}^{+}\right)$, stem cells $\left(\mathrm{CD} 4 \mathrm{f}^{\mathrm{hi}} / \mathrm{EpCAM}^{-}\right)$, and $\mathrm{CD}_{4} 4^{+} /$ CD24-/low populations is necessary to assess this hypothesis. This point is emphasized by the fact that stem cell marker ALDH1 [14] is expressed by only some of the cells in either fractions described above yet ALDH1 ${ }^{+}$cells exhibit the greatest TIC capacity.

The underlying hypothesis assumes that, within the dynamic steady state of breast epithelial maintenance, self-renewal, and differentiation (as it responds to 
lactation-related breast augmentation) and the successive involution, cancer arises from specific intermediary states and somehow maintains the molecular profile of its cell of origin [15]. It is indeed remarkable that breast cancer cell lines can be subdivided into the same molecular subtypes as primary cancer [16]. However, these observations are good in only first-degree approximation since molecular profiling of tissue whole mass cannot capture the incredible heterogeneity of cancer populations [17]. Although cellular heterogeneity severely hinders our ability to assign stem cell phenotype and markers on the single-cell level, recent advances in expression profiling of single cells [18] may shed more light on this mystery. Nevertheless, population analysis still informs our understanding of TIC markers. By employing fluorescence-activated cell sorting (FACS) and carefully appraising each marker, Keller and colleagues [1] find that CD44 is a relatively promiscuous marker whereas EpCAM, CD24, and CD49f demonstrate extensive heterogeneity within cultured populations of the investigated cell lines. Interpreting these results in terms of self-renewal and morphological phenotypes (such as mammosphere and xenograft growth efficiency) or mesenchymal appearance further demonstrated the complexity of differentiation states, as judged by a handful of markers. The authors benchmark the progenitor cell population by assuming that the overall self-renewal phenotype of a given cell line's mixed population should correlate with the abundance of the particular population allegedly capable of the self-renewal. Further support to their cell fraction-self-renewal assignment is still needed from direct cell population subfractionation by using FACS similar to that performed by Al-Hajj and colleagues [7].

Stem cell 'purification' may gain insight from a biochemical purification scheme, in which successive fractionation results in diminishing yields and increasing specific activity. For example, consider the purification of mitosis-promoting factor (MPF). For a long time, conflicting reports claimed that MPF depends on or is attenuated by phosphatase activity. Ultimately, it was recognized that the activity was dependent, in a sequential fashion, on both the kinase activity of MPF and the phosphatase activity of CDC25. It is agreed that, in normal tissue, progenitors are regulated by signals from their respective niche. However, assays for the activity of self-renewal, which not only mimic the niche more effectively but potentially involve mixing back the isolated cells with other cell populations at the onset of the assay (much to the same effect as mixing homogenous basal transcription factors in an in vitro reconstituted transcription reaction), have not yet been employed. Consequently, as was the case for MPF, it is possible that all current reports rely on mixed populations. In support of this notion, the claudin-low candidate TIC-like cancers are also elevated with leukocyte infiltrate signature [10], which could reflect the role of heterotypic interactions that regulate progenitor phenotype in vivo, but not in current model systems. Such rigorous reconstitution experiments, with trackable cell progeny, may offer new handles with which to control, rather than monitor, breast stem cells.

\section{Abbreviations}

FACS, fluorescence-activated cell sorting; MPF, mitosis-promoting factor; TIC, tumor-initiating cell.

\section{Competing interests}

The author declares that he has no competing interests.

\section{Author details}

'Systems Integration and Bioinformatics, The Blood and DNA Profiling Facility, Baker IDI, 75 Commercial Road, Prahran, Vic, 3004 Australia; 2Department of Biochemistry, School of Medicine, The University of Melbourne, 161 Barry Street, Parkville, Vic, 3000 Australia; ${ }^{3}$ Metastasis Research Laboratory, Peter MacCallum Cancer Centre, 1 St Andrew's Place, East Melbourne, Vic, 3002 Australia.

Published: 25 January 2011

\section{References}

1. Keller PJ, Lin AF, Arendt LM, Klebba I, Jones AD, Rudnick JA, Dimeo TA, Gilmore $H$, Jefferson DM, Graham RA, Naber SP, Schnitt S, Kuperwasser C: Mapping the cellular and molecular heterogeneity of normal and malignant breast tissues and cultured cell lines. Breast Cancer Res 2010, 12:R87.

2. Smalley M, Ashworth A: Stem cells and breast cancer: a field in transit. Nat Rev Cancer 2003, 3:832-844.

3. Lopez-Garcia MA, Geyer FC, Lacroix-Triki M, Marchio C, Reis-Filho JS: Breast cancer precursors revisited: molecular features and progression pathways. Histopathology 2010, 57:171-192.

4. Perou CM, Sørlie T, Eisen MB, van de Rijn M, Jeffrey SS, Rees CA, Pollack JR, Ross DT, Johnsen H, Akslen LA, Fluge O, Pergamenschikov A, Williams C, Zhu SX, Lønning PE, Børresen-Dale AL, Brown PO, Botstein D: Molecular portraits of human breast tumours. Nature 2000, 406:747-752.

5. Shipitsin M, Campbell LL, Argani P, Weremowicz S, Bloushtain-Qimron N, Yao J, Nikolskaya T, Serebryiskaya T, Beroukhim R, Hu M, Halushka MK, Sukumar S, Parker LM, Anderson KS, Harris LN, Garber JE, Richardson AL, Schnitt SJ, Nikolsky Y, Gelman RS, Polyak K: Molecular definition of breast tumor heterogeneity. Cancer Cell 2007, 11:259-273.

6. Mani SA, Guo W, Liao MJ, Eaton EN, Ayyanan A, Zhou AY, Brooks M, Reinhard F, Zhang CC, Shipitsin M, Campbell LL, Polyak K, Brisken C, Yang J, Weinberg RA: The epithelial-mesenchymal transition generates cells with properties of stem cells. Cell 2008, 133:704-715.

7. Al-Hajj M, Wicha MS, Benito-Hernandez A, Morrison SJ, Clarke MF: Prospective identification of tumorigenic breast cancer cells. Proc Natl Acad Sci U S A 2003, 100:3983-3988.

8. Tomaskovic-Crook E, Thompson EW, Thiery JP: Epithelial to mesenchymal transition and breast cancer. Breast Cancer Res 2009, 11:213.

9. Lim E, Vaillant F, Wu D, Forrest NC, Pal B, Hart AH, Asselin-Labat ML, Gyorki DE, Ward T, Partanen A, Feleppa F, Huschtscha LI, Thorne HJ; kConFab, Fox SB, Yan M, French JD, Brown MA, Smyth GK, Visvader JE, Lindeman GJ: Aberrant luminal progenitors as the candidate target population for basal tumor development in BRCA1 mutation carriers. Nat Med 2009, 15:907-913.

10. Prat A, Parker JS, Karginova O, Fan C, Livasy C, Herschkowitz JI, He X, Perou CM: Phenotypic and molecular characterization of the claudin-low intrinsic subtype of breast cancer. Breast Cancer Res 2010, 12:R68.

11. Molyneux G, Geyer FC, Magnay FA, McCarthy A, Kendrick H, Natrajan R, Mackay A, Grigoriadis A, Tutt A, Ashworth A, Reis-Filho JS, Smalley MJ: BRCA1 basal-like breast cancers originate from luminal epithelial progenitors and not from basal stem cells. Cell Stem Cell 2010, 7:403-417.

12. Eirew P, Stingl J, Raouf A, Turashvili G, Aparicio S, Emerman JT, Eaves CJ: A method for quantifying normal human mammary epithelial stem cells with in vivo regenerative ability. Nat Med 2008, 14:1384-1389. 
13. Villadsen R, Fridriksdottir AJ, Ronnov-Jessen L, Gudjonsson T, Rank F, LaBarge MA, Bissell MJ, Petersen OW: Evidence for a stem cell hierarchy in the adult human breast. J Cell Bio/ 2007, 177:87-101.

14. Ginestier C, Hur MH, Charafe-Jauffret E, Monville F, Dutcher J, Brown M, Jacquemier J, Viens P, Kleer CG, Liu S, Schott A, Hayes D, Birnbaum D, Wicha MS, Dontu G: ALDH1 is a marker of normal and malignant human mammary stem cells and a predictor of poor clinical outcome. Cell Stem Cell 2007, 1:555-567.

15. Korsching E, Jeffrey SS, Meinerz W, Decker T, Boecker W, Buerger H: Basal carcinoma of the breast revisited: an old entity with new interpretations. J Clin Pathol 2008, 61:553-560.

16. Neve RM, Chin K, Fridlyand J, Yeh J, Baehner FL, Fevr T, Clark L, Bayani N, Coppe JP, Tong F, Speed T, Spellman PT, DeVries S, Lapuk A, Wang NJ, Kuo WL, Stilwell JL, Pinkel D, Albertson DG, Waldman FM, McCormick F, Dickson RB, Johnson MD, Lippman M, Ethier S, Gazdar A, Gray JW: A collection of breast cancer cell lines for the study of functionally distinct cancer subtypes. Cancer Cell 2006, 10:515-527.

17. Fidler IJ, Kripke ML: Genomic analysis of primary tumors does not address the prevalence of metastatic cells in the population. Nat Genet 2003, 34:23; author reply 25 .

18. Kurimoto K, Saitou M: Single-cell cDNA microarray profiling of complex biological processes of differentiation. Curr Opin Genet Dev 2010, 20:470-477.

doi:10.1186/bcr2792

Cite this article as: Haviv l: Appraisal of progenitor markers in the context of molecular classification of breast cancers. Breast Cancer Research 2011, 13:102. 